\title{
Review of the quality of studies on the economic effects of smoke-free policies on the hospitality industry
}

\author{
M Scollo, A Lal, A Hyland, S Glantz
}

Tobacco Control 2003;12:13-20

See end of article for authors' affiliations

Correspondence to: Michelle Scollo, VicHealth

Centre for Tobacco Control, The Cancer

Council, Victoria,

100 Drummond Street,

Carlton, 3053, Australia;

michelle.scollo@

cancervic.org.au

Received

1 October 2002

Accepted

20 October 2002

\begin{abstract}
Objective: To compare the quality and funding source of studies concluding a negative economic impact of smoke-free policies in the hospitality industry to studies concluding no such negative impact. Data sources: Researchers sought all studies produced before 31 August 2002. Articles published in scientific journals were located with Medline, Science Citation Index, Social Sciences Citation Index, Current Contents, Psychlnfo, Econlit, and Healthstar. Unpublished studies were located from tobacco company websites and through internet searches.

Study selection: 97 studies that made statements about economic impact were included. $93 \%$ of the studies located met the selection criteria as determined by consensus between multiple reviewers.

Data extraction: Findings and characteristics of studies (apart from funding source) were classified independently by two researchers. A third assessor blind to both the objective of the present study and to funding source also classified each study.

Data synthesis: In studies concluding a negative impact, the odds of using a subjective outcome measure was 4.0 times (95\% confidence interval $(\mathrm{Cl}) 1.4$ to $9.6 ; \mathrm{p}=0.007$ ) and the odds of not being peer reviewed was 20 times $(95 \% \mathrm{Cl} 2.6$ to $166.7 ; p=0.004)$ that of studies concluding no such negative impact. All of the studies concluding a negative impact were supported by the tobacco industry. $94 \%$ of the tobacco industry supported studies concluded a negative economic impact compared to none of the non-industry supported studies.

Conclusion: All of the best designed studies report no impact or a positive impact of smoke-free restaurant and bar laws on sales or employment. Policymakers can act to protect workers and patrons from the toxins in secondhand smoke confident in rejecting industry claims that there will be an adverse economic impact.
\end{abstract}

S moke-free workplace policies reduce both exposure to secondhand tobacco smoke and cigarette consumption. ${ }^{1-3}$ Smoke-free restaurants and bars similarly reduce exposure to tobacco smoke toxins among hospitality workers and patrons but also represent a serious business threat to the tobacco industry.

In California in 1987, a 100\% smoke-free restaurant ordinance in Beverly Hills was rolled back, partly in response to claims that the ordinance was responsible for reducing restaurant revenues by $30 \%$, claims which later turned out to be unsubstantiated. ${ }^{4}$ Since then, tobacco companies and allied groups have routinely predicted that enactment of such legislation would severely impact restaurant and bar sales and employment. ${ }^{5-9}$ Health advocates, by contrast, have presented studies indicating that no such adverse effects actually occurred..$^{10}$

Policymakers are typically presented with a large amount of conflicting material, with evidence ranging from anecdotes about individual businesses ${ }^{11}$ to scientific studies analysing objective information collected independently across an entire hospitality sector. ${ }^{12}$ Such data are often confusing to interpret and it is difficult for policymakers to reach an evidence based conclusion. In their case study of deliberations by the Maryland Occupational Safety and Health Advisory Board, Montini et al demonstrate that those opposing proposed smoke-free workplace regulations lodged twice the number of submissions as those supporting it, but that evidence from opponents was substantially less scientifically rigorous than evidence provided by supporters of workplace smoking regulations. ${ }^{13}$ Similar findings were observed in relation to the Californian Environmental Protection Agency's risk assessment of secondhand smoke, ${ }^{14}$ and in Maryland and Washington hearings on proposed clean indoor air regulations. ${ }^{15}$ Bero and her colleagues have repeatedly called on advocates to more forcefully draw to legislators' attention the superior scientific quality of the evidence base relied upon by public health groups in calling for clean air legislation. ${ }^{13-15}$

This paper compares the quality of evidence and conclusions about the economic impact of smoke-free laws on the hospitality industry based on the type of data used, how the studies are designed, analysed and interpreted, and the funding source.

\section{METHODS}

\section{Data source}

Studies included in this analysis are listed in a comprehensive summary produced by the VicHealth Centre for Tobacco Control. ${ }^{16}$ Centre researchers attempted to locate all studies produced in English before 31 August 2002 that purported to assess the economic impact of smoke-free policies in the hospitality industry. Peer reviewed articles were located with Medline, Science Citation Index, Social Sciences Citation Index, Current Contents, PsychInfo, Econlit, and Healthstar using the terms smok* and restaurants, bars, hospitality, economic, regulation and law. Unpublished studies were also included in the analysis. These studies were located from a compilation by the Alberta Tobacco Control Centre, ${ }^{10}$ by a request to members of the International Union Against Cancer's International Tobacco Control Network (GLOBALink), and an examination of hospitality industry websites and the websites of tobacco companies based in major English speaking countries, including the Philip Morris "Options" website, www.pmoptions.com . The researchers also conducted an internet search with the Google search engine www.google.com , using the terms "smok* bans" and "restaurants" or "bars", limited by the terms "economic impact" or "study". 


\section{Study selection}

Studies included measured changes in sales, employment, numbers of establishments, bankruptcy data, public reports of intentions about or recent changes in patronage, spending or time spent dining, proprietors predictions or perceptions of sales changes and costs and estimated numbers of tourists. Studies were excluded where these made no explicit or implicit attempt to quantify the economic impact of smoking restrictions. Studies assessing opinions about smoke-free policy were included where the study included a question asking specifically whether people would attend venues more or less frequently were such policies to be introduced.

Ninety three per cent of the studies located (97/104) met the selection criteria as determined by consensus between multiple reviewers.

\section{DATA EXTRACTION}

Findings and characteristics of studies (apart from funding source) were classified independently by two researchers in most cases several months before the start of the study (MS and $\mathrm{AL}$ ). Both assessors had tertiary qualifications in behavioural science and economics. A third assessor, (LH) a postgraduate psychology student blind to both the objective of the present study and to the funding source, also classified each study.

We used Siegel's criteria ${ }^{12}$ to judge study quality: use of objective data (for example, tax receipts or employment statistics); inclusion of all data points after the law was implemented and several years before; use of regression or other statistical methods that control for secular trends and random fluctuation in the data; and appropriate control for overall economic trend. The more criteria a particular study met, the more certain one can be about the validity of results.

An outcome measure was deemed "objective" if it was based on data collected routinely by an independent agency covering the periods both before and after the smoke-free policy was in force. Objective measures included: sales figures provided for the purposes of taxation assessment; employment figures provided to government agencies generally for insurance purposes; and numbers of new or existing establishments based on business permit applications or registrations to the government agency that issues such permits, and bankruptcy data.

Unverifiable predictions of future changes or estimates of recent changes in patronage or spending were deemed "subjective". Subjective measures included anecdotal reports and self report data collected in polls of, or interviews with, patrons or owners of restaurants, bars or similar businesses, conducted either before or after the policy was put in place.

Another indicator of the quality of a study is whether it has been subject to peer review. The scientific quality of original research on secondhand smoke published in peer reviewed journals is superior to that in non-peer reviewed publications in terms of study design, reporting, and evaluation. ${ }^{17}$ A study was deemed to have been peer reviewed if it was an article published in an academic journal.

Studies were classified as indicating or not indicating a negative economic effect based on their stated conclusions about the impact or potential impact on employment or profitability of the various sections of the hospitality industry at issue. All three raters agreed on the conclusions in all but one of the 97 studies. The Masotti study ${ }^{18}$ was classified as negative, as per the conclusion of two of the three raters. Two studies ${ }^{19}{ }^{20}$ did not draw conclusions; we included them in the analysis based on their face-value findings.

Funding sources for each paper were noted after completion of all the other classification tasks. Funding was determined from acknowledgments in the studies (obscured on copies of papers classified by the third rater). When the source was not clearly disclosed, authors were contacted where possible and attempts were made to determine whether authors or sponsoring agencies had ever received financial support from a tobacco company or affiliated group. Searches were undertaken of previously secret tobacco industry documents made available as part of settlement agreements between tobacco companies the US attorneys general ${ }^{21} 22$ (accessible through www.tobaccoarchives.com ).

\section{Analyses}

We used contingency tables and odds ratios to compare studies concluding a negative impact with those not concluding a negative impact.

\section{DATA SYNTHESIS}

A total of 97 reports were located. ${ }^{518-20} 23-115$. Studies covered numerous local jurisdictions in 31 state or provincial areas, in eight countries. Thirty four of the studies examined the impact of smoke-free policies for drinking establishments, and 90 the impact of smoke-free policies for restaurants. Two studies examined the impact for recreational venues. One examined the impact of smoke-free restaurants on hotels and another on overall tourism.

\section{Study quality}

Of the 97 studies, 38\% (37/97) used objective outcome measures and 25\% (24/97) were peer reviewed. Twenty one studies met Siegel's four criteria for methodological quality, representing 57\% (21/37) of the studies that used objective measures. By contrast, $98 \%$ (59/60) of the studies using only subjective outcome measures met none of the criteria. The odds of peer reviewed articles meeting all four criteria was 5.33 times that of non-peer reviewed studies (95\% confidence interval (CI) 1.9 to $15.1 ; \mathrm{p}=0.002$ ).

\section{Funding source}

Of the 97 studies, 32\% (31) were funded either by the tobacco industry or a group known to have received funding from a tobacco company or tobacco industry ally. ${ }^{19} 202357$ 59-61 80-83 84 86-97 103107108114 Four studies did not disclose funding source, but were conducted by consultants or organisations known to have a connection with the tobacco industry. ${ }^{18315885}$ For three of these studies, there was strong evidence of collaboration between tobacco companies and the study authors. ${ }^{3158} 85$

The two studies by consultants where close ties with the tobacco industry had been established and those funded by organisations known to have received funding from the tobacco industry were included with the tobacco industry funded studies, yielding 31 tobacco industry supported studies. The funding source was treated as missing for six studies $^{18} 2799$ 104-106 because no data on funding source could be located.

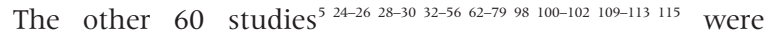
funded either by government, health related organisations or independent market research organisations.

All the studies used in this analysis is summarised in tables 1 and 2 .

\section{Study quality and funding}

The methodological quality of the industry sponsored studies was significantly lower $(\mathrm{p}<0.001)$ than the non-industry studies (table 3 ). Only one of the 31 tobacco industry supported studies (3\%) has been published in a peer reviewed journal compared to $38 \%(23 / 60)$ of the non-industry funded studies. None $(0 / 31)$ of the tobacco industry supported studies met all of Siegel's ${ }^{12}$ four methodological quality criteria. Indeed, 84\% (26/31) of the industry supported studies met none of the criteria. By contrast, 35\% (21/60) of the studies not supported by the tobacco industry met all of Siegel's ${ }^{12}$ 
Table 1 Studies using objective measures to assess economic impact of smoke-free policies in the hospitality industry

\begin{tabular}{|c|c|c|c|c|}
\hline & Control for economic conditions & & Do not control for economic cc & ditions \\
\hline & No effect, or positive effect & $\begin{array}{l}\text { Negative } \\
\text { effect }\end{array}$ & No effect, or positive effect & Negative effect \\
\hline Studies funded $f$ & from sources other than the tobacco industry & & & \\
\hline $\begin{array}{l}\text { Taxable sales } \\
\text { receipts }\end{array}$ & 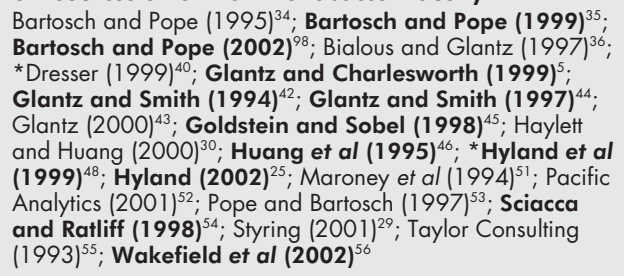 & & $\begin{array}{l}\text { California State Board of } \\
\text { Equalization }(1998)^{37} \text {; }{ }^{*} \text { City of } \\
\text { Boulder }(1996)^{38} \text {; Fletcher } \\
(1998)^{41}\end{array}$ & \\
\hline Sales data other & & & ${ }^{*}$ Dresser et al $(1999)^{39}$ & \\
\hline $\begin{array}{l}\text { Employment } \\
\text { levels }\end{array}$ & $\begin{array}{l}\text { *Hild et al } 20011^{113} \text {; }{ }^{*} \text { Hyland and Cummings }(1999)^{47} \text {; } \\
{ }^{*} \text { Hyland and Tuk }(2001)^{50} ; \text { Hyland et al }(2000)^{49} ; \text { Bourns } \\
\text { and Malcomson }{ }^{33}\end{array}$ & & & \\
\hline $\begin{array}{l}\text { Number of } \\
\text { establishments }\end{array}$ & ${ }^{*}$ Hyland and Cummings (1999) ${ }^{47}$ & & & \\
\hline Bankruptcy data & Bourns and Malcomson ${ }^{33}$ & & & \\
\hline Studies for whic & $\mathrm{h}$ funding is unknown & & & \\
\hline Sales data other & & & & Pubco $2002^{27}$ \\
\hline $\begin{array}{l}\text { Studies conduct } \\
\text { Taxable sales } \\
\text { receipts }\end{array}$ & ed by organisations or consultants with links to the tobace & 0 industry & und the time of the study & $\begin{array}{l}\text { *Lilley et al }(1996)^{61} \\
{ }^{*} \text { Masolti et al } \\
(1991)^{18} \dagger\end{array}$ \\
\hline Studies funded $\mathrm{t}$ & by tobacco companies or industry groups supported by th & e tobacco i & stry & \\
\hline $\begin{array}{l}\text { Taxable sales } \\
\text { receipts }\end{array}$ & & & & $\begin{array}{l}\text { *Laventhol et al } \\
(1990)^{58}\end{array}$ \\
\hline Sales data other & & & & $\begin{array}{l}\text { Applied economics } \\
(1996)^{57}\end{array}$ \\
\hline $\begin{array}{l}\text { Employment } \\
\text { levels }\end{array}$ & & & & $\begin{array}{l}\text { *Lilley et al } \\
(1999)^{59} ;{ }^{*} \text { Lilley et } \\
\text { al }(1996)^{00}\end{array}$ \\
\hline $\begin{array}{l}\text { Number of } \\
\text { establishments }\end{array}$ & & & & *Lilley et al $1999^{59}$ \\
\hline
\end{tabular}

criteria $^{5} 2530$ 33-36 42-46 $484951-5698$ ( $p<0.001$ ). Eleven of these nonindustry funded studies have been published in peer reviewed journals.

\section{Study quality and conclusion}

Table 4 sets out the findings of those studies meeting each of various indicators of high quality: using objective outcome measures; meeting this and Siegel's other three criteria for quality; being funded by a source clearly independent of the tobacco industry; and being peer reviewed.

None of the 21 studies that met all four of Siegel's ${ }^{12}$ quality criteria reported a negative impact (table 4). In fact, four of the studies report a positive impact on taxable sales receipts of restaurants, bars, hotels, or tourism..$^{564348}$

Only a handful of studies based on objective data conclude a negative impact. None of these meets more than one of Siegel's other three criteria for methodological quality. Only one peer reviewed study concluded a negative impact. ${ }^{84}$ This study relied on subjective data and was funded by a tobacco company.

Table 5, conversely, shows, for those studies concluding negative impact, whether each of the various quality criteria was met. Once again, studies concluding a negative impact rarely included an objective measure and were almost never peer reviewed.

In studies concluding a negative impact, the odds of using only a subjective measure was 4.0 times (95\% CI 1.4 to 9.9; $\mathrm{p}=0.007)$ and the odds of being peer reviewed was 20 times (95\% CI 2.6 to $166.7 ; p=0.004$ ) that of studies concluding no such negative impact (table 6)

\section{Funding source and conclusion}

There was a significant association of tobacco industry support with negative conclusions of the study $(\mathrm{p}<0.001)$ (table 6). Ninety four per cent (29/31) of the tobacco industry supported studies concluded that there was or would be a negative economic impact of implementing a smoke-free policy. The odds ratio for a negative conclusion associated with tobacco industry support was infinite because none of the 60 non-industry funded studies concluded a negative economic impact.

\section{DISCUSSION}

Lower quality studies were much more likely to conclude smoke-free regulations adversely impact the hospitality industry, and weaker studies were much more likely to be 
Table 2 Studies using subjective measures to assess the economic impact of smoke-free policies in the hospitality industry

\begin{tabular}{|c|c|}
\hline & No effect or positive effect \\
\hline $\begin{array}{l}\text { Studies funded from sources other than } \\
\text { Public self reported intentions or actual } \\
\text { patronage of restaurants/bars }\end{array}$ & $\begin{array}{l}\text { the tobacco industry } \\
\text { Allen and Markham }(2001)^{100} ; \text { August }(2000)^{62} ; \text { Biener and } \\
\text { Fitzgerald }(1999)^{63} ; \text { Biener and Siegel }(1997)^{64} ; \text { Corsun et } \\
\text { al (1996) }{ }^{65} ; \text { Decima Research }(2001)^{67} ; \text { Decima Research } \\
(2002)^{32} ; \text { Dresser et al }(1999)^{39} ; \text { Field Research }(1998)^{70} ; \text { Field } \\
\text { Research }(1997)^{69} ; \text { Hyland and Cummings }(1999)^{71} ; \text { Lam } \\
\text { (1995) }^{193} ; \text { McGhee } 2002^{24} ; \text { Miller and Kriven }(2002)^{28} ; \text { Miller } \\
\text { and Kriven }(2002)^{26} ; \text { Shapiro } 2001^{112} ; \text { Styring }(2001)^{29} ; \\
\text { Wakefield et al 1999 }\end{array}$ \\
\hline $\begin{array}{l}\text { Proprietor predictions/ perceptions of sales } \\
\text { changes }\end{array}$ & $\begin{array}{l}\text { Allen and Markham }(2001)^{100} ; \text { Cremieux and Oulette } \\
(2001)^{66} ; \text { Dresser et al }(1999)^{39} ; \text { Edwards }(2000)^{68} ; \text { Huron } \\
\text { County Health Unit 1999111; Hyland and } \\
\text { Cummings }(1999)^{72} \ddagger \text {; Jones et al }(1999)^{115} ; \text { Markham and } \\
\text { Tong }(2001)^{74} ; \text { Parry et al }(2001)^{78} ; \text { Sciacca and Eckram } \\
(1993)^{75} ; \text { Sciacca }(1996)^{76} ; \text { Stanwick }(1998)^{77} \text {; The } \\
\text { Conference Board of Canada }(1996)^{79} ; \text { Yorkshire Ash }(2001)^{102}\end{array}$ \\
\hline
\end{tabular}

Proprietor predictions/perceptions of cost Cremieux and Oulette (2001) (66 $^{66}$ The Conference Board of

Estimated numbers of overseas visitors

Canada (1996) ${ }^{79}$; Douglas County CHIP (2001) $)^{110}$

Hodges and Maskill (2001) ${ }^{109}$

Studies for which funding source is unknown

Proprietor predictions/ perceptions of sales

Economists Advisory Group (1998)105;

changes

Negative effect

Studies conducted by organisations or consultants with some links to the tobacco industry around the time of the study

Proprietor predictions/ perceptions of sales Masotti et al $(1991)^{18} \dagger$

changes

CCG 1996 ${ }^{104}$; Charlton Research (1994) $)^{83}$

Studies funded by tobacco companies or industry groups supported by the tobacco industry

Public self reported intentions or actual Auspoll (2000) ${ }^{19}$; Decima research $(1988)^{20}$

patronage of restaurants/bars

Fabrizio et al (1995) ${ }^{107}$; KPMG Barents (1997) ${ }^{23}$; Marlow (1999) 87 ; National Restaurant Association (1993) ${ }^{91}$; Sollars et al (1999) ${ }^{95}$

Public self reported spending/time spent

Fabrizio et al (1995) ${ }^{107}$; Martin Associates $\underline{(1999)^{89}}$

Proprietor predictions/ perceptions of sales changes

Advantage Marketing Info (1997)

Applied Economics (1996) ${ }^{81} ;$ CCG

$1995^{103}$; Chamberlain Research

Consultants (1998)

Marlow (2000) ${ }^{84}$; EMRS $2001^{114}$;

Fabrizio et al (1996) ${ }^{108}$; Gambee (1991) ${ }^{85}$;

KPMG Peat Marwick (1998) ${ }^{86}$; KPMG

$(2001)^{31}$; Marlow (1999) ${ }^{87}$; Marlow

(1998): Mason-Dixon Market Research

${ }^{(1996)^{90}}$; Price Waterhouse LLP (1993)

Price Waterhouse LLP (1995) ${ }^{92}$; Roper

Starch (1996) ${ }^{94}$; The Craig Group Inc

${ }^{(1998)^{96}}$; The Eppstein Group (1997)

Proprietor estimates of impact on

employment

Advantage Marketing Info (1997) ${ }^{80}$;

Applied Economics (1996) ${ }^{81}$; Fabrizio et al

$(1996)^{108}$; Marlow (1998) ${ }^{88}$; Price

Waterhouse LLP (1993) ${ }^{93} ;$ Roper Starch

(1996) $^{94}$; Sollars et al (1999)

Chamberlain Research Consultants

${ }^{(1998)^{82}}$; The Eppstein Group (1997)

Proprietor predictions/perceptions of cost

Sollars et al (1999) 95

Bold type $=$ peer reviewed; underline $=$ study based on estimates of predicted changes rather than estimates of actual changes

* Not a random survey.

†Only weak evidence of connection with the tobacco industry.

$\ddagger$ Control for economic trends.

funded by the tobacco industry. In addition, the industry studies were less likely to be published in the peer reviewed literature. Almost all (94\%) of industry supported studies, compared to none of the studies funded by sources other than the tobacco industry, claimed a negative economic impact.

These results are consistent with a similar linkage between tobacco industry funding and conclusions in reviews of the effects of secondhand smoke. ${ }^{116}$ Barnes and Bero ${ }^{116}$ identified 106 reviews of the relation between secondhand smoke and disease. Thirty seven per cent of these reviews concluded that passive smoking was not harmful to health; $74 \%$ of these reviews were written by authors with tobacco industry affiliations. Among reviews written by individuals with no industry affiliations, only $13 \%$ (10/75) reached the conclusion that passive smoking is not harmful to health. In logistic regression analyses controlling for article quality, peer review status, article topic, and publication year, the only factor associated with concluding that passive smoking is not harmful was whether an author was affiliated with the tobacco industry (odds ratio 88.4; $\mathrm{p}<0.001$ ). 
Table 3 Quality of studies supported by the tobacco industry compared with those that are not

\begin{tabular}{|c|c|c|c|c|}
\hline Percent of studies . . . & $\begin{array}{l}\text { Industry supported } \\
\text { studies }\end{array}$ & Non-industry studies & Odd ratios $(95 \% \mathrm{Cl})$ & p Value \\
\hline $\begin{array}{l}\text { Including an objective } \\
\text { outcome measure }\end{array}$ & $18 \%(5 / 31)^{57-61}$ & $\begin{array}{l}50 \%(30 / 60)^{525293033-56} \\
98113\end{array}$ & $5.2(1.7$ to 15.4$)$ & 0.003 \\
\hline $\begin{array}{l}\text { Meeting all four } \\
\text { methodological criteria }\end{array}$ & $0 \%(0 / 31)$ & $\begin{array}{l}35 \%(21 / 60) 525293034-36 \\
42-46484951-5698\end{array}$ & Infinite & \\
\hline Subject to peer review & $3 \%(1 / 31)^{84}$ & $\begin{array}{l}38 \%(23 / 60)^{5} 354244-4954 \\
5663-66717275-7798101115\end{array}$ & 18.5 (2.4 to 142.9 ) & 0.005 \\
\hline
\end{tabular}

Table 4 Findings of higher quality studies

\begin{tabular}{|c|c|c|c|c|}
\hline & \multicolumn{2}{|c|}{ Conclusion of negative impact? } & \multirow[b]{2}{*}{$\chi^{2}$} & \multirow[b]{2}{*}{$\mathrm{p}$ Value } \\
\hline & Yes & No & & \\
\hline $\begin{array}{l}\text { Meeting all four Siegel criteria } \\
(n=21)\end{array}$ & $0 \%(0 / 21)$ & $\begin{array}{l}100 \%(21 / 21)^{525293034-36} \\
42-46484951-5698\end{array}$ & 15.13 & 0.000 \\
\hline $\begin{array}{l}\text { Including an objective measure } \\
(n=37)\end{array}$ & $19 \%(7 / 37)^{182757-61}$ & $\begin{array}{l}81 \%(30 / 37) 525293033-5698 \\
113\end{array}$ & 7.64 & 0.006 \\
\hline $\begin{array}{l}\text { Funded by source clearly } \\
\text { independent of the tobacco } \\
\text { industry }(n=60)\end{array}$ & $0 \%(0 / 60)$ & $\begin{array}{l}100 \%(60 / 60)^{5} 24-2628-30 \\
32-5662-7998100-102109-113115\end{array}$ & 82.38 & 0.000 \\
\hline Peer reviewed $(n=24)$ & $4 \%(1 / 24)^{84}$ & $\begin{array}{l}96 \%(23 / 24)^{5} 354244-495456 \\
63-667275-7798101115\end{array}$ & 14.09 & 0.000 \\
\hline
\end{tabular}

Table 5 Quality of studies among those that reported a negative impact

\begin{tabular}{|c|c|c|c|c|}
\hline & Yes & No & $\chi^{2}$ & $\mathrm{p}$ Value \\
\hline Meeting all four Siegel criteria & $0 \%(0 / 35)$ & $\begin{array}{l}100 \%(35 / 35)^{18} 232731 \\
57-6180-9799103-108114\end{array}$ & 15.13 & 0.000 \\
\hline Including an objective measure & $20 \%(7 / 35)^{182757-61}$ & $\begin{array}{l}80 \%(28 / 35)^{233180-9799} \\
103-108114\end{array}$ & 7.64 & 0.006 \\
\hline $\begin{array}{l}\text { Funded by source clearly } \\
\text { independent of tobacco industry }\end{array}$ & $0 \%(0 / 35)$ & $\begin{array}{l}100 \%(35 / 35)^{18232731} \\
57-6180-9799103-108114\end{array}$ & 88.80 & 0.000 \\
\hline Peer reviewed & $3 \%(1 / 35)^{84}$ & $\begin{array}{l}97 \%(34 / 35)^{18233157-61} \\
80-9799103-108114\end{array}$ & 14.09 & 0.000 \\
\hline
\end{tabular}

Table 6 Odds ratios for indicators of lower quality among studies with negative conclusions compared to studies not concluding a negative impact

\begin{tabular}{|c|c|c|c|c|}
\hline & $\begin{array}{l}\% \text { finding a } \\
\text { negative outcome }\end{array}$ & $\begin{array}{l}\% \text { not finding a negative } \\
\text { outcome }\end{array}$ & $\begin{array}{l}\text { Odds ratios } \\
(95 \% \mathrm{Cl})\end{array}$ & $\begin{array}{l}\mathrm{p} \\
\text { Value }\end{array}$ \\
\hline $\begin{array}{l}\text { Including only subjective } \\
\text { outcome measures }\end{array}$ & $\begin{array}{l}80 \%(28 / 35)^{23} 31 \\
80-9799103-108114\end{array}$ & $\begin{array}{l}52 \%(32 / 62) 192024262832 \\
62-79100-102109-112115\end{array}$ & 4.0 (1.4 to 9.9) & 0.007 \\
\hline $\begin{array}{l}\text { Funded by the tobacco } \\
\text { industry or a group supported } \\
\text { by the tobacco industry }\end{array}$ & $\begin{array}{l}94 \%(29 / 31)^{2331} \\
57-6180-97103107108114\end{array}$ & $4 \%(2 / 62)^{1920}$ & Infinite & 0.001 \\
\hline Not being peer reviewed? & $\begin{array}{l}97 \%(34 / 35)^{18} 57-61 \\
80-8385-9799103-108114\end{array}$ & $\begin{array}{l}63 \%(39 / 62) 192024-2628-30 \\
32-3436-414350-53556267-707374 \\
7879100102109-113\end{array}$ & 20 (2.6 to 166.7) & 0.004 \\
\hline
\end{tabular}


The possibility of publication bias always exists. It is possible that studies by those sympathetic to public health goals that detect a negative impact would be less likely to be submitted for publication. On the other hand those funded by the tobacco industry would be similarly unlikely to release studies detecting no negative impact. We have made every effort to identify all studies done on the effects of smoke-free laws and regulations on the hospitality industry. The fact that the tobacco industry has a strong motivation to publicise all negative studies adds to our confidence that we have not missed a substantial number of studies concluding a negative economic impact.

Siegel's criteria are a valuable tool for assessing the quality of studies on the economic impact of smoke-free policies in the hospitality industry. Our findings suggest that policymakers can make a quick preliminary assessment of study quality by asking three questions:

(1) Was the study funded by a source clearly independent of the tobacco industry?

(2) Did the study objectively measure what actually happened, or was it based on subjective predictions or assessments?

(3) Was it published in a peer reviewed journal?

Of the 35 studies on this topic published that concluded a negative impact, none have been funded by a source clearly independent of the tobacco industry, and none have both used an objective measure and been peer reviewed. In fact, $80 \%$ of these studies passed none of these basic tests of quality. With all 21 of the well designed studies finding that smoke-free restaurant and bar laws had no negative impact on revenue or jobs, policymakers can act to protect workers and patrons from the toxins in secondhand smoke confident in rejecting predictions that there will an adverse economic impact.

\section{ACKNOWLEDGEMENTS}

Thanks to Dr Mohammad Siahpush from the VicHealth Centre for Tobacco Control for advice on statistical analysis, and Louisa Hoey for assistance with classification of studies.

The VicHealth Centre for Tobacco Control is funded by the Victorian Health Promotion Foundation to conduct economic, legal, and social research in tobacco control. Dr Hyland's work was supported by the Roswell Park Cancer Institute NCI-funded Cancer Center Support Grant, CAl6056-26 as a member of the Biomathematics/Biostatistics Core Resource. Dr Glantz's work was supported by US National Cancer Institute grant CA-61021.

\section{Authors' affiliations}

M Scollo, A Lal, VicHealth Centre for Tobacco Control, The Cancer Council, Victoria, Melbourne, Victoria, Australia

A Hyland, Roswell Park Cancer Institute, Department of Cancer Prevention, Epidemiology, and Biostatistics, Buffalo, New York, USA S Glantz, Institute of Health Policy Studies and Cardiovascular Research Institute, University of California, San Francisco, California, USA

\section{REFERENCES}

1 Chapman S, Borland R, Scollo M, et al. The impact of smoke-free workplaces on declining cigarette consumption in Australia and the United States. Am J Public Health 1999;89:1018-23.

2 Fichtenberg CM, Glantz SA. Effect of smoke-free workplaces on smoking behaviour: systematic review. BM 2002;325:188.

3 Burns D, Shanks T, Major J, et al. Restrictions on smoking in the workplace. In: US Department of Health and Human Services, Public Health Service, National Institute of Health, National Cancer Institute, eds. Population based smoking cessation. Bethseda; 2000.

4 Samuels B, Glantz S. The politics of local tobacco control. JAMA 1991;266:2110-7

5 Glantz S, Charlesworth A. Tourism and hotel revenues before and after passage of smoke-free restaurant ordinances. JAMA 1999;281:1911-

6 Magzamen S, Glantz S. The new battleground: California's experience with smoke-free bars. Am J Public Health 2001:91:245-52.

7 Ritch WA, Begay ME. Strange bedfellows: the history of collaboration between the Massachusetts Restaurant Association and the tobacco industry. Am J Public Health 2001;91:598-603
8 Mangurian C. Bero LA. Lessons learned from the tobacco industries' efforts to prevent the passage of a work place smoking regulation. Am J Public Health 2000;90:1926-30.

9 Dearlove J, Bialous S, Glantz S. Tobacco industry manipulation of the hospitality industry to maintain smoking in public places. Tobocco Control (in press).

10 Alberta Tobacco Control Centre. The economic impact of smoke-free restaurant bylaws. Edmonton: Alberta Tobacco Control Centre, 1999.

11 Magzamen S, Charlesworth A, Glantz S. Print media coverage of California's smokefree bar law. Tobacco Control 2001;10:154-60.

12 Siegel M. Economic impact of 100\% smoke-free restaurant ordinances. In: Smoking and restaurants: a guide for policy makers. Berkeley: UC Berkeley/UCSF Preventative Medicine Residency Program; American Heart Association, California Affiliate; Alameda County Health Care Services Agency, Tobacco Control Program; 1992

13 Montini T, Bero L. Policy makers' perspectives on tobacco control advocates' roles in regulation development. Tobacco Control 2001:10:218-24.

14 Schotland $M$, Bero L. Evaluating public commentary an scientific evidence submitted in the development of risk assessment. Risk Analysis 2002; 22:131-40.

15 Bero L, Montini T, Bryan-Jones K, et al. Science in regulatory policy making: case studies in the development of workplace smoking restrictions. Tobacco Control 2001; 10:329-36.

16 Scollo M, Lal A. Summary of studies assessing the economic impact of smoke-free policies in the hospitality industry - includes studies produced to 31 August 2002. Melbourne: VicHealth Centre for Tobacco Control; 2002. http://www.vctc.org.au/publ/reports/ hospitality_paper_summary.pdf.

17 Barnes DE, Bero LA. Scientific quality of original research articles on environmental tobacco smoke. Tobacco Control 1997:6:19-26.

18 Masotti L, Creticos P. The effects of a ban on smoking in public places in San Luis Obispo California; 1991.

19 Auspoll. Philip Morris Public Opinion Survey; 2000 January.

20 Decima Research. Focus group report on project visa for Imperial Tobacco. 1988. Access date: 24 September 2001. URL: http://www.tobaccodocuments.org/ view. cfm?CitlD=5772634\&GetListArrayldx=. 1\&Showlmage s=yes.

21 Dyer C. Confidential tobacco documents enter public domain. BM 1998;316:1186

22 Malone RE, Balbach ED. Tobacco industry documents: treasure trove or quagmire? Tobacco Control 2000;9:334-8.

23 KPMG Barents Group LLC. The expected economic impact on Spain of a ban in smoking in restaurants. Washington; 1997 April.

24 Mcghee S, Hedley A, Lam T. Does the government's proposal to create smoke-free catering facilities in restaurants, cafes, bars and karaokes influence the intentions of tourists to visit Hong Kong and to patronise catering venues. Hong Kong: Health Services Research Group, Department of Community Medicine, University of Hong Kong, March 2002.

25 Hyland A. Before and after smoke-free regulations in new taxable sales from eating and drinking places in New York State. New York: Roswell Park Cancer Institute, June 2002

26 Miller C, Kriven S. Smoke-free dining in South Australia: surveys of community attitudes and practices after 4 and 18 months. In: Tobacco control research and evaluation report 1998-2001. Adelaide: Tobacco Control Research Evaluation Unit, 2002.

27 Pubco. Official figures from Ontario brewers confirm disastrous effects of smoking ban. Pub and Bar Coalition of Ontario. 2002. Access date: 26 August 2002. URL: http://www.smokeinottawa.com/html/index.html.

28 Miller C, Kriven S. Community support for smoking bans in bar and gaming venues in South Australia.In: Tobacco control research and evaluation report 1998-2001. Adelaide: Tobacco Control Research Evaluation Unit, 2002

29 Styring W. A study of the Fort Wayne (IN) restaurant smoking ban: has it impacted the restaurant business? Indianapolis: Hudson Institute, 2001.

30 Hayslett J, Huang P. Impact of clean indoor air ordinances on restaurant revenues in four Texas cities. Bureau of Disease, Injury and Tobacco Prevention, Texas Department of Health, 2000

31 KPMG. Proposed smoking ban: impacts on Hong Kong hospitality businesses. Hong Kong Catering Industry Association, September 2001.

32 Decima Research Inc. Public support grows for city's smoking by-law. Decima Research Inc. 2002. Access date: 26 August 2002. URL: http://www.decima.ca/research/WhatsNew/index.asp?lD=57.

33 Bourns B, Malcomson A. Economic impact analysis of the non-smoking bylaw on the hospitality industry in Ottawa. KPMG, 2001.

34 Bartosch W, Pope G. Preliminary analysis of the economic impact of Brooklines smoking ban. Massachusetts: Health Economics Research Inc 1995.

35 Bartosch W, Pope G. The economic effect of smoke-free restaurant policies on restaurant businesses in Massachusetts. J Public Health Manag Pract 1999;5(1):53-62.

36 Bialous S, Glantz S. Tobacco control in Arizona. Institute for Health Policy Studies, University of California. 1997. Access date: 8 August 2001. URL: www.library.ucsf.edu/tobacco/az.

37 California State Board of Equalization. Report 13 October 1998.

38 City of Boulder Colorado. Tax receipt data, 1996.

39 Dresser J, Boles S, Lichtenstein E, et al. Multiple impacts of a bar smoking prohibition ordinance in Corvallis, Oregon. Pacific Research Institute, 1999.

40 Dresser L. Clearing the air. Wisconsin: Tobacco-Free Wisconsin Coalition, 1999 
41 Fletcher J. An analysis of sales tax receipts from restaurants with bars and free standing bars in Chico, California 1995-1997. California Department of Health Services, Tobacco Control Section, 1998

42 Glantz S, Smith L. The effect of ordinances requiring smoke-free restaurants on restaurant sales. Am J Public Health 1994;84:1081-5.

43 Glantz S. Effect of smokefree bar law on bar revenues in California. Tobacco Control 2000;9:111-2.

44 Glantz S, Smith L. The effect of ordinances requiring smoke-free restaurants and bars on revenues: a follow up. Am J Public Health 1997;87: 1687-93

45 Goldstein A, Sobel R. Environmental tobacco smoke regulations have not hurt restaurant sales in North Carolina. North Carolina Med J 1998;59:284-7.

46 Huang $\mathbf{P}$, Tobias S, Kohout S, et al. Assessment of the impact of a $100 \%$ smoke-free ordinances on restaurant sales - West Lake Hills, Texas, 1992-1994. MMWR Morb Mortal Wkly Rep 1995;44:370-2.

47 Hyland A, Cummings K. Restaurant employment before and after the New York City Smoke-free Air Act. J Public Health Manag Pract $1999 ; 5(1): 22-7$

48 Hyland A, Cummings K, Navenberg E. Analysis of taxable sales receipts: was New York City's Smoke-free Air Act bad for business? J Public Health Manag Pract 1999;5(1): 14-21.

49 Hyland A, Vena C, Cummings K, et al. The effect of the Clean Air Act of Erie County, New York on restaurant employment. J Public Health Manag Pract 2000;6(6):76-85

50 Hyland A, Tuk J. Restaurant employment boom in New York City. Tobacco Control 2001;10:199-200.

51 Maroney N, Sherwood D, Stubblebine W. The impact of tobacco control ordinances on restaurant revenues in California. Claremont, California: The Claremont Institute for Economic Policy Studies, 1994.

52 Pacific Analytics Inc. The economic impacts of the proposed amendment to the ETS regulation. 2001. Access date: 3 August 2001. URL: http://www.worksafebc.com/priority/smoke/pdfs/ecoimpact.pdf.

53 Pope G, Bartosch W. Effect of local smokefree restaurant policies on restaurant revenue in Massachusetts. Center for Health Economics Research, April 1997

54 Sciacca J, Ratliff M. Prohibiting smoking in restaurants: effects on restaurant sales. Am J Health Promot 1998;12:176-84.

55 Taylor Consulting Group. The San Luis Óbispo smoking ordinance: $s$ study of the economic impacts of San Luis Obispo restaurants and bars. San Luis Obispo, California, 1993

56 Wakefield $M$, Siahpush M, Scollo M, et al. The effect of a smoke-free law on monthly restaurant retail turnover in South Australia. Aust NZ J Public Health 2002;26:375-82.

57 Applied Economics. Economic impact of the City of Mesa smoke-free ordinance: working paper 2. 1996. Access date: 9 August 2001. URL: http://www.pmoptions.com/images/EcononmiclmpactMesa2.pdf.

58 Laventhol \& Horwath. Preliminary analysis of the impact of the proposed Los Angeles ban on smoking in restaurants. Los Angeles,

59 Lilley W, DeFranco L. The impact of smoking restrictions on the bar and tavern industry in California. Washington: InContext Inc, 26 October 1999

60 Lilley W, DeFranco L. Restaurant jobs in New York City, 1993 through first quarter 1996, and the restaurant smoking ban. 1996. Access date: 13 September 2001. URL: http://www.pmoptions.com/images/ RestaurantJobs.pdf.

61 Lilley W, DeFranco L. Massachusetts restaurant smoking ban 23 cities/towns: impact on restaurant jobs 1993-1995. 1996. Access date: 13 September 2001. URL: http://www.pmoptions.com/images/ MassRestaurant.pdf.

62 August K, Brooks L. Support for smoke-free bars grows stronger in California: California Department of Health Services, 2000.

63 Biener L, Fitzgerald G. Smoky bars and restaurants: who avoids them and why. J Public Health Manag Pract 1999;5(1):74-8.

64 Biener L, Siegel M. Behavior intentions of the public after bans in restaurants and bars. Am J Public Health 1997;87:2042-4

65 Corsun D, Young C, Enz C. Should NYC's restaurateurs lighten up? Effects of the city's Smoke-free Air Act. Cornell Hotel Restaurant Adm Q 1996;37(2):25-33.

66 Cremieux P, Oullette P. Actual and perceived impacts of tobacco regulation on restaurants and firms. Tobacco Control 2001;10:33-7.

67 Decima Research. Ottawa residents back smoking ban by two to one. 2001 . Access date: 19 October 2001. URL: http://www.decima.ca/ research/WhatsNew/011017.asp.

68 Edwards R. New Study: $76 \%$ of the North East hospitality trade back smoke free areas \& over $90 \%$ of publicans recommend other pubs try one. 2000. Access date: 8 August 2001. URL: http://www.ash.org.uk/ $\mathrm{html} /$ press/000720.html.

69 Field Research Corporation. A survey of California adults age 21 or older about smoking policies and smoke-free bars. California: California Department of Health Services, July 1997

70 Field Research Corporation. A survey of California bar patrons about smoking policies and smoke-free bars: California Department of Health Services, March 1998.

71 Hyland A, Cummings K. Consumer response to the New York City smoke-free air act. J Public Health Manag Pract 1999;5(1):28-36.

72 Hyland A, Cummings K. Restaurateur reports of the economic impact of the New York City Smoke-free Air Act. J Public Health Manag Pract 1999;5(1):37-42.

73 Lam T, Chung S, Tam E, et al. Public opinion on smoke-free restaurants. Hong Kong: Department of Community Medicine, The University of Hong Kong, October 1995
74 Markham V, Tong R. Reactions and attitudes to health (smoking in enclosed places) regulations 1999. 2001. Access date: 3 August 2001. URL: http://acosh.org/library_fr_set.htm.

75 Sciacca J, Eckram M. Effects of a city ordinance regulating smoking in restaurants and retail stores. J Community Health 1993;18:175-82.

76 Sciacca J. A mandatory smoking ban in restaurants: concerns versus experiences. J Community Health 1996;21:133-150.

77 Stanwick R, Thomson M, Swerhone P, et al. The response of Winnipeg retail shops and restaurants to a bylaw regulating smoking in public places. Can J Public Health 1988;79:226-30.

78 Parry J, Temperton $\mathrm{H}$, Flanagan $\mathrm{T}$, et al. An evaluation of the impact of the introduction of "non-smoking" areas on trade and customer satisfaction in 11 public houses in Staffordshire. Tobacco Control 2001; 10:199-200

79 Conference Board of Canada. The economics of smoke-free restaurants. Toronto, 1996

80 Advantage Marketing Information. Rhode Islander's attitudes towards smoking in restaurants and hotels. 1997. Access date: 13 September 2001. URL: http://www.pmoptions.com/images/Rhodelsland.pdf.

81 Applied Economics. Economic impact of the City of Mesa smoke-free ordinance: working paper 1. 1996. Access date: 8 August 2001. URL http://www.pmoptions.com/images/EcononmiclmpactMesal pdf.

82 Chamberlain Research Consultants. Smoking issues in Wisconsin. 1998. Access date: 13 September 2001. URL: http:// www.pmoptions.com/images/Wisconsin.pdf.

83 Charlton Research Group. Pacific Dining Car Restaurant and Southern California Business Association Survey. San Francisco, 1994.

84 Dunham J, Marlow M. Smoking laws and their differential effects on restaurants, bars and taverns. Contemporary Economic Policy 2000; 18:326-33

85 Gambee P. Economic impacts of smoking ban in Bellflower California California Business and Restaurant Alliance (CBRA), 1991.

86 KPMG Peat Marwick LLP. The impact of California's smoking ban on bars, taverns and night clubs: A survey of owners and managers. Washington DC: KPMG, 1998

87 Marlow M. An economic analysis of the Maine smoking ban: evidence from patrons and owners of businesses California Polytechnic State University, 1999.

88 Marlow M. The economic effect of smoking laws on bars and taverns. California Polytechnic University, 1998.

89 Martin Associates. Analysis of passenger expenditure profiles at Phoenix Sky Harbour International Airport in-concession survey. 1999. Access date: 13 September 2001. URL: http://www.pmoptions.com/ images/PHOENIX.pdf.

90 Mason-Dixon Market Research. Maryland smoking regulation survey. 1996. Access date: 9 August 2001. URL: http://www.pmoptions.com/ images/Maryland.pdf

91 National Restaurant Association. Smoking in restaurants a consumer attitude survey. Washington DC, 1993.

92 Price Waterhouse LLP. New York City restaurant survey. 1995. Access date: 8 August 2001. URL: http://www.pmoptions.com/images/ NewYork.pdf.

93 Price Waterhouse. Potential effects of a smoking ban in the State of California. 1993. Access date: 9 August 2001. URL: http:// www.pmoptions.com/images/PotentialEconomicEffects.pdf.

94 Roper Starch. National survey of restaurants and bars/taverns: smoking policy and regulations. 1996. Access date: 9 August 2001. URL: http://www.pmoptions.com/images/NationalSurvey.pdf.

95 Sollars D, Ingram J. Economic impact of the restaurant smoking ban in the city of Massachusetts, May 51999.

96 The Craig Group Inc. West Virginia restaurants and taverns fear smoking bans would hurt business, 1998

97 The Eppstein Group. 1997 statewide hospitality industry benchmark poll. 1997. Access date: 13 September 2001. URL: http:// www.pmoptions.com/images/Texas.pdf.

98 Bartosch W, Pope G. The effect of smoking restrictions on restaurant business in Massachusetts, 1992-1998. Tobacco Control 2002;11 (suppl II):ii38-42.

99 Pubco. September Pubco survey confirms severe economic impact, job losses in its member bars and pubs. 2001. Access date: 28 November 2001. URL: http://www.pubcoalition.com/html/.

100 Allen K, Markham V. Public opinions and attitudes towards creating smokefree bars in Western Australia. ACOSH, November 2001

101 Wakefield M, Roberts L, Miller C. Perceptions of the effect of an impending restaurant smoking ban on dining-out experience. Prev Med 1999:29:53-6.

102 Yorkshire Ash. Popularity and impact on trade of smoke-free accommodation in the hospitality trade in Yorkshire; 2001

103 CCG Consulting Group Limited. The hospitality sector and a Vancouver smoking ban, 1995. Access date: 3 December 2001. URL: http://193.78.190.200/evhosp/restaur/restaur.htm.

104 CCG Consulting Group. The food services and hospitality sector and a metro Toronto smoking ban. 1996. Access date: 3 December 2001 URL: http://193.78.190.200/evhosp/restaur/restaur.htm.

105 Economists Advisory Group Ltd. The potential economic impact of a smoking ban in restaurants. The Restaurant Association, September 1998.

106 The Publican Newspaper. Reading the smoke signals. Market Report 2001: smoking 2001. p 22

107 Fabrizio McLaughlin and Associates Inc. Impact of smoking bans on smokers dining out patterns derived from national survey of adults smokers. 1995. Access date: 3 December 2001. URL: http://www.forces.org/evidence/evid/bans.htm. 
108 Fabrizio McLaughlin and Associates Inc. Survey of New York City Restaurateurs. 1996. Access date: 3 December 2001. URL: http://193.78.190.200/evhosp/fabnysrv.htm.

109 Hodges I, Maskill C. Assessing the potential impact of restaurant and bar smoking bans on visitors to New Zealand. Auckland: Healthsearch, 18 January 2001

110 Douglas County Community Health Improvement Project. Douglas County Business Smoking Survey, June 2001.

111 Huron County Health Unit. Huron County Health Unit restaurant survey, June 1999.

112 Shapiro T. Butt of the law hits restaurants. Business Day, 15 August 2001
113 Hild C, Larson E, Weiss L, et al. Review of Municipality of Anchorage Chapter 16.65 - prohibition of smoking in public places. Institute for Circumpolar Health Studies, October 2001

114 Enterprise Marketing and Research Services. The effects of recent events on the Tasmanian hotel industry, November 2001.

115 Jones K, Wakefield M, Turnball D. Attitudes and experiences of restaurateurs regarding smoking bans in Adelaide, South Australia. Tobacco Control 1999;8:62-6.

116 Barnes DE, Bero LA. Why review articles on the health effects of passive smoking reach different conclusions. JAMA 1998;279:1566-70.

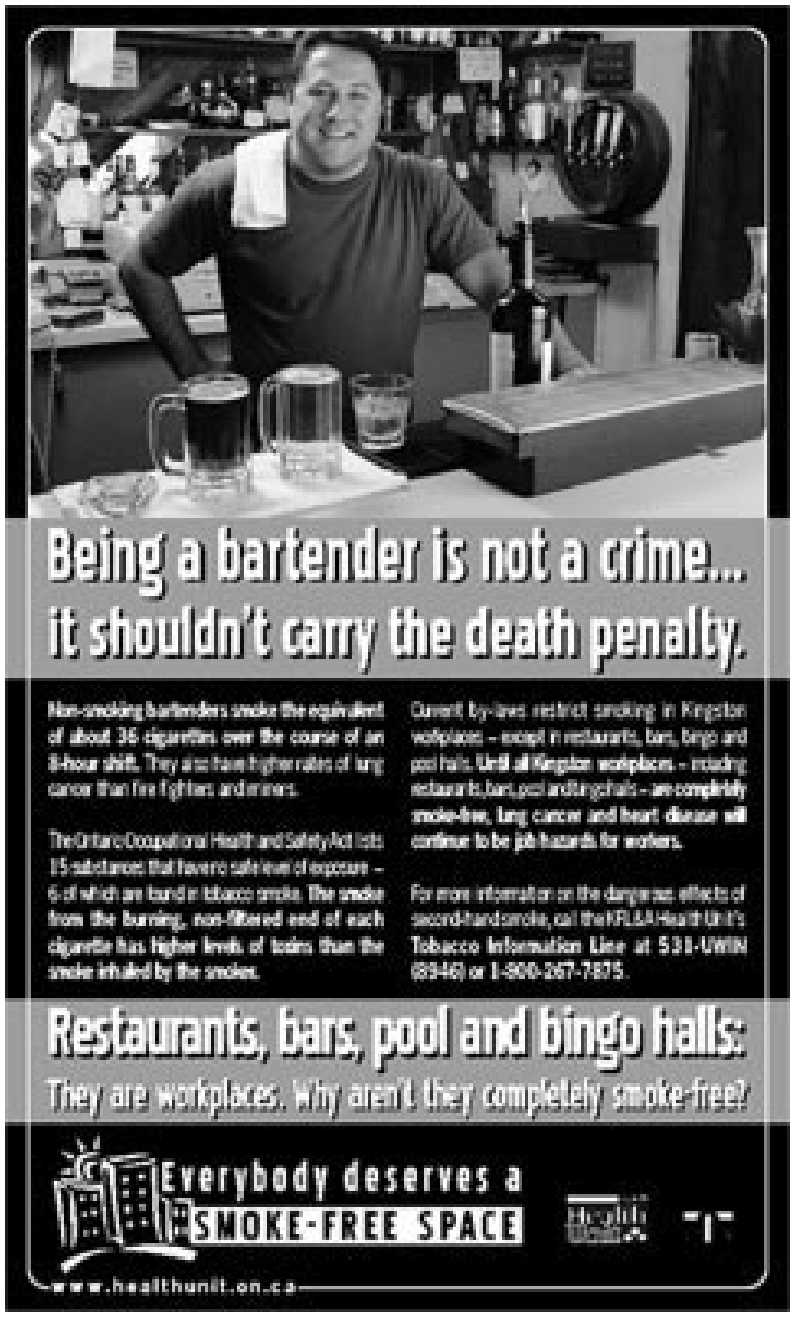

City of Kingston, Canada: Smoke-free By-law Campaign 2002. OKingston, Frontenac and Lennox \& Addington Health Unit - J. Chenier. 